\title{
A GORGEOUS GALLERY OF GALLANT INVENTIONS
}


LONDON : HUMPHREY MILFORD

OXFORD UNIVERSITY PRESS 


\section{A Gorgeous Gallery of Gallant Inventions ( 1578$)$}

EDITED BY HYDER E. ROLLINS

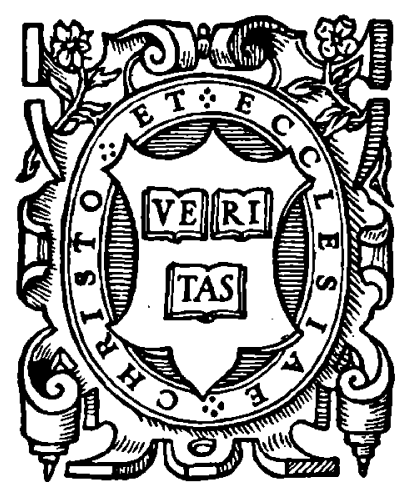

CAMBRIDGE

HARVARD UNIVERSITY PRESS

I 926 
COPYRIGHT, 1926

BY HARVARD UNIVERSITY PRESS

PRINTED AT THE HARVARD UNIVERSITY PRESS

CAMBRIDGE, MASS., U.S.A. 
To

ADDIE FRANCES ROWE

The good genius of an entire generation of Harvard men

In gratitude and friendship. 
